\title{
Use of Antibiotics and Knowledge of Antibiotics Resistance by Selected Farmers in Oyo Town, Nigeria
}

\author{
B.O. Oyebanji ${ }^{1, *}$, M. O. Oyebisi ${ }^{1}$ \\ ${ }^{1}$ Department of Animal Sciences, Obafemi Awolowo University. \\ *Corresponding author. (C) oyebanji.bukola44@gmail.com (6) +2347032765674
}

\begin{abstract}
This survey was carried out to investigate antibiotics usage and knowledge of antibiotic resistance among farmers in Oyo town, Nigeria. Data was collected using a questionnaire and interviews. A snowball sampling technique was used to select 150 farmers and veterinary drug shop owners. The famers were involved in cattle, fish and poultry faming. The farmers administered antibiotics to their animals when the animals were sick (curative), to prevent secondary bacterial infection after a viral infection and on healthy animals (for prophylaxis). Majority of the respondents had easy access to antibiotics and information about them. On average, farmers had some knowledge about antibiotics resistance but not on how it spread. About $62 \%$ of the respondents believed that antibiotic resistance was a problem of other countries not Nigeria. They also did not believe that sub-optimal dosing of antibiotics leads to resistance. It was concluded that there is need for public awareness on the risk of misuse of antibiotics in animals and of consuming livestock products with unsafe levels of antibiotic residues.
\end{abstract}

Keywords: Antibiotics, Drug resistance, Livestock.

\section{INTRODUCTION}

Antibiotics are naturally occurring, semisynthetic and synthetic compounds with antimicrobial activity that can be applied parentally, orally or topically (Geidam et al., 2009). They are among the most widely used veterinary drugs in the livestock industry (Simon and Baxter, 2006) to enhance growth rates, health, feed efficiency, production, or for therapeutic reasons (Dipeolu et al., 2002; Donoghue, 2003).

In Nigeria, a large population of poultry, fish and cattle farming is done by the socalled backyard farmers who readily have access to veterinary (vet) drugs and quite often purchase drugs over the counter for administration without veterinary prescription and supervision. This results in the indiscriminate use of these drugs, especially in food animals (Dipeolu, 2004). Consequently, the inappropriate use and handling of these antibiotics has led to occurrence of harmful residues in edible animal products like milk (Olatoye and Ehinmowo, 2009; Shareef et al., 2009). Veterinary drug residues in animal products may be produced by exposing animals to drugs or contaminants in a numbers of ways including:

- Failure to adhere to official drug use instructions.

- Use of feed unintentionally cross contaminated during feed mixing 
- Use of mislabelled feed

- Pesticide, chemical or heavy metal contamination of feed ingredients or water (Donoghue, 1998; Donoghue, 2001; Sasanya et al., 2005; Doyle, 2006).

Currently, a large populace of Nigeria is at high risk of ill-health caused by the consumption of animal products from animals with toxic levels of antibiotic residues. Taking cognizance of this risk, this study was conducted to assess the knowledge of antibiotics and antibiotics resistance among cattle, poultry and fish farmers and veterinary drug shop owners in Oyo town Nigeria.

\section{METHODS}

The study was conducted in Oyo town, Oyo State, Nigeria. A close ended questionnaire was used to seek information from farmers about the use of antibiotics on their various farms. Questionnaire was used in face-to-face interview with the farmers. The research maintained absolute confidentially throughout the study. A total of 150 respondents consisting of poultry farmers, fisheries farmers, cattle farmers and vet shop owners were interviewed.

\section{RESULTS}

Table 1: Socio-economic characteristics

\begin{tabular}{|c|c|c|c|c|c|c|}
\hline & & $\begin{array}{l}\text { Poultry } \\
\mathrm{n}(54)\end{array}$ & $\begin{array}{l}\text { Fishery } \\
\mathrm{n}(34)\end{array}$ & $\begin{array}{l}\text { Cattle } \\
\mathrm{n}(34)\end{array}$ & $\begin{array}{l}\text { Vet shop } \\
\text { operators } \mathrm{n}(28)\end{array}$ & $\begin{array}{l}\text { Total } \\
150\end{array}$ \\
\hline \multirow[t]{2}{*}{ Gender } & Male & $38(70.37 \%)$ & $24(70.59 \%)$ & $27[79.41]$ & $19(67.86 \%)$ & $108(72 \%)$ \\
\hline & Female & $16(29.63 \%)$ & $10(29.41 \%)$ & $7[20.59]$ & $9(32.14 \%)$ & $42(28 \%)$ \\
\hline \multirow[t]{5}{*}{ Age } & $20-30$ & $3(5.56 \%)$ & $3(8.82 \%)$ & $4(11.76 \%)$ & $3(10.71 \%)$ & $13(8.67 \%)$ \\
\hline & $31-40$ & $6(11.11 \%)$ & $7(20.59 \%)$ & $16(47.06 \%)$ & $8(28.56 \%)$ & $37(24.67 \%)$ \\
\hline & $41-50$ & $25(46.30 \%)$ & $15(44.12 \%)$ & $4(11.76 \%)$ & $10(35.71 \%)$ & $54(36 \%)$ \\
\hline & $51-60$ & $16(29.63 \%)$ & $5(14.71 \%)$ & $5(14.71 \%)$ & $4(14.29 \%)$ & $30(20 \%)$ \\
\hline & $61+$ & $4(7.41 \%)$ & $4(11.76 \%)$ & $5(14.71 \%)$ & $3(10.71 \%)$ & $16(10.67 \%)$ \\
\hline \multirow{4}{*}{$\begin{array}{l}\text { Marital } \\
\text { status }\end{array}$} & Married & $31(57.41 \%)$ & $20(58.82 \%)$ & $20(58.83 \%)$ & $23(82.14 \%)$ & $94(62.67 \%)$ \\
\hline & Single & $17(31.48 \%)$ & $12(35.29 \%)$ & $10(29.41 \%)$ & $4(14.29 \%)$ & $43(28.67 \%)$ \\
\hline & Widow & $0(0 \%)$ & $2(5.88 \%)$ & $3(8.82 \%)$ & $1(3.57 \%)$ & $6(4 \%)$ \\
\hline & Divorced & $6(11.11 \%)$ & $0(0 \%)$ & $1(2.94 \%)$ & $0(0 \%)$ & $7(4.67 \%)$ \\
\hline Family & $1-5$ & $9(16.67 \%)$ & $14(41.18 \%)$ & $1[2.94 \%]$ & $6(21.43 \%)$ & $30(20 \%)$ \\
\hline \multirow[t]{2}{*}{ size } & $6-10$ & $25(46.30 \%)$ & $10(29.41 \%)$ & $4[11.76 \%]$ & $16(57.14 \%)$ & $55(36.67 \%)$ \\
\hline & $11+$ & $20(30.04 \%)$ & $10(29.41 \%)$ & $13[38.24 \%]$ & $6(21.43 \%)$ & $49(32.67 \%)$ \\
\hline \multirow[t]{8}{*}{ Education } & Illiterate & $0(0 \%)$ & $2(5.88 \%)$ & $22(64.71 \%)$ & $0(0 \%)$ & $24(16 \%)$ \\
\hline & Primary & $1(1.85 \%)$ & $1(2.94 \%)$ & $8(23.53 \%)$ & $0(0 \%)$ & $10(6.67 \%)$ \\
\hline & SSCE & $22(40.74 \%)$ & $15(44.12 \%)$ & $2(5.88 \%)$ & $5(17.86 \%)$ & $44(29.33 \%)$ \\
\hline & NCE & $6(11.11 \%)$ & $1(2.94 \%)$ & $0 \%$ & $6(21.43 \%)$ & $13(8.67 \%)$ \\
\hline & OND & $6(11.11 \%)$ & $8(23.53 \%)$ & $0 \%$ & $0(0 \%)$ & $14(9.33 \%)$ \\
\hline & HND & $3(5.55 \%)$ & $5(14.71 \%)$ & $0 \%$ & $2(7.14 \%)$ & $10(6.67 \%)$ \\
\hline & $\mathrm{BSc}$ & $16(29.63 \%)$ & $2(5.88 \%)$ & $2(5.88 \%)$ & $14(50 \%)$ & $34(22.67 \%)$ \\
\hline & MSc & $0(0 \%)$ & $0(0 \%)$ & $0 \%$ & $1(3.57 \%)$ & $1(0.67 \%)$ \\
\hline
\end{tabular}

The result of socio- economic parameters is presented in Table 1. It was observed that male constituted majority in poultry, fish, cattle and vet shop owner. In poultry $70.37 \%$ were males while females were $29.63 \%$, in fishery $70.59 \%$ were male while 
female were $29.41 \%$, in cattle production $79.41 \%$ were male while female were $20.59 \%, 67.86 \%$ of vet shop owners were male while females were $32.14 \%$. The highest number of farmers were with the age range of 41-50 years and most of the farmers were married. SSCE holders were in the majority, and there were no $\mathrm{PhD}$ holders among the farmers. Sixteen percent $(16 \%)$ of the respondents were illiterate with $67.7 \%$ of these being cattle farmers.
From Table 2, 36\% of the respondents were poultry farmers, and $22.67 \%$ were fish farmers, while $22.67 \%$ were cattle farmers and $18.67 \%$ were vet shop owners. About Eleven percent $(11.48 \%)$ of the respondents practiced extensive, and $39.34 \%$ practiced semi intensive, and $47.54 \%$ practiced intensive system of farming (Table 3).

Table 2. Animal Species.

\begin{tabular}{lll}
\hline & Frequency & $(\%)$ \\
\hline Layers birds & 54 & 36.0 \\
Fishery & 34 & 22.67 \\
Cattle & 34 & 22.67 \\
Vet shop & 28 & 18.67 \\
Total & 150 & 100 \\
\hline
\end{tabular}

Table 3. Production System

\begin{tabular}{lllll}
\hline Parameter & Poultry & Fishery & Cattle & Total \\
\hline Extensive & $6(11.11 \%)$ & $0(0 \%)$ & $8(23.53 \%)$ & $11.48 \%$ \\
Semi intensive & $18(33.33 \%)$ & $10(29.41 \%)$ & $20(58.82 \%)$ & $39.34 \%$ \\
Intensive & $30(55.56 \%)$ & $24(70.59 \%)$ & $4(11.76 \%)$ & $47.54 \%$ \\
\hline
\end{tabular}

Table 4. Access to antibiotics and information related to antibiotics.

\begin{tabular}{|c|c|c|c|c|c|c|}
\hline & & $\begin{array}{l}\text { Poultry } \\
\mathrm{n}(54)\end{array}$ & $\begin{array}{l}\text { Fishery } \\
\mathrm{n}(34)\end{array}$ & $\begin{array}{l}\text { Cattle } \\
\mathrm{n}(34)\end{array}$ & $\begin{array}{l}\text { Vet Shop } \\
\text { operators } \mathrm{n}(28)\end{array}$ & Overall \\
\hline \multirow[t]{4}{*}{$\begin{array}{l}\text { Access to } \\
\text { antibiotics }\end{array}$} & Very Easy & $\begin{array}{l}15 \\
(27.78 \%)\end{array}$ & $\begin{array}{l}5 \\
(14.71 \%)\end{array}$ & $\begin{array}{l}7 \\
(20.59 \%)\end{array}$ & $1(3.57 \%)$ & $18.67 \%$ \\
\hline & Easy & $\begin{array}{l}35 \\
(64.81 \%)\end{array}$ & $\begin{array}{l}27 \\
(79.41 \%)\end{array}$ & $\begin{array}{l}25 \\
(73.53 \%)\end{array}$ & $27(96.43 \%)$ & $76 \%$ \\
\hline & Difficult & $4(7.41 \%)$ & $1(2.94 \%)$ & $1(2.94 \%)$ & $0 \%$ & $4 \%$ \\
\hline & Very Difficult & $0 \%$ & $1(2.94 \%)$ & $1(2.94 \%)$ & $0 \%$ & $1.33 \%$ \\
\hline \multirow[t]{4}{*}{$\begin{array}{l}\text { Access to } \\
\text { information }\end{array}$} & Very easy & $\begin{array}{l}16 \\
(29.63 \%)\end{array}$ & $\begin{array}{l}5 \\
(14.71 \%)\end{array}$ & $\begin{array}{l}10 \\
(29.41 \%)\end{array}$ & $1(3.57 \%)$ & $21.33 \%$ \\
\hline & Easy & $\begin{array}{l}35 \\
(64.81 \%)\end{array}$ & $\begin{array}{l}27 \\
(79.41 \%)\end{array}$ & $\begin{array}{l}20 \\
(58.82 \%)\end{array}$ & $25(89.29 \%)$ & $71.33 \%$ \\
\hline & Difficult & $3(5.56 \%)$ & $0 \%$ & $1(2.94 \%)$ & $2(7.14 \%)$ & $4 \%$ \\
\hline & Very Difficult & $0 \%$ & $2(5.88 \%)$ & $3(8.82 \%)$ & $0 \%$ & $3.33 \%$ \\
\hline \multirow[t]{2}{*}{$\begin{array}{l}\text { Sources of } \\
\text { information }\end{array}$} & $\begin{array}{l}\text { Mobile } \\
\text { Salesmen }\end{array}$ & $\begin{array}{l}30 \\
(55.56 \%)\end{array}$ & $\begin{array}{l}19 \\
(55.88 \%)\end{array}$ & $\begin{array}{l}22 \\
(64.71 \%)\end{array}$ & $9(32.14 \%)$ & $53.33 \%$ \\
\hline & Drug leaflet & $\begin{array}{l}24 \\
(44.44 \%)\end{array}$ & $\begin{array}{l}15 \\
(44.11 \%)\end{array}$ & $\begin{array}{l}12 \\
(35.29 \%)\end{array}$ & $19(67.86 \%)$ & $46.67 \%$ \\
\hline
\end{tabular}

Majority of the respondents from all the categories survey had easy access to antibiotics with poultry farmers at $64.81 \%$, fish farmers at $79.41 \%$, cattle farmers at 
$73.53 \%$ and vet shop owners at $96.43 \%$, this was also true for access to information about antibiotics. Knowledge of farmers about antibiotics is presented in Table 5 . On the average, farmers have some knowledge about antibiotics resistance with about $50 \%$ knowing there is something called antibiotics resistance. The score became low when farmers were asked about how this resistance spread, with majority responding that person to person spread is not possible, and that animal to human spread is also false, they responded that it occurred in people taking antibiotics alone.
About $62 \%$ believed that antibiotic resistance was a problem of other countries but not Nigeria. They also did not believe that sub-optimal dosing of antibiotics that lead to resistance.

Table 6 indicated that oxytetracycline $(72.78 \%)$ were the most commonly used among the respondents. In vet shop the bestselling antibiotics was oxytetracycline which constituted $89.29 \%$ followed by doxycycline which is $82.14 \%$ and tyrosine which constituted $64.29 \%$. Majority of the farmers had no idea about the super bugs and antibiotic resistance bacteria (Table 8). 
Table 5. Knowledge of antibiotics resistance among farmers

\begin{tabular}{|c|c|c|c|c|c|}
\hline Variables & Poultry & Fishery & Cattle & Vet shop operators & Overall \\
\hline \multicolumn{6}{|c|}{ Antibiotics resistance occurs when your body becomes resistance to antibiotics and they no longer work as well. } \\
\hline True & $35(64.81 \%)$ & $16(47.06 \%)$ & $20(58.82 \%)$ & $16(57.14 \%)$ & $87(58.0 \%)$ \\
\hline False & $19(35.19 \%)$ & $18(52.94 \%)$ & $14(41.18 \%)$ & $12(42.86 \%)$ & $63(42 \%)$ \\
\hline Total & 54 & 34 & 34 & 28 & 150 \\
\hline \multicolumn{6}{|c|}{ Many infections are becoming increasingly resistant to treatment by antibiotics } \\
\hline True & $30(55.56 \%)$ & $20(58.82 \%)$ & $18(52.94 \%)$ & $18(64.29 \%)$ & $86(57.33 \%)$ \\
\hline False & $24(44.44 \%)$ & $14(41.18 \%)$ & $16(47.66 \%)$ & $10(35.71 \%)$ & $64(42.67 \%)$ \\
\hline Total & 54 & 34 & 34 & 28 & 150 \\
\hline \multicolumn{6}{|c|}{ If bacteria are resistant to antibiotics it can be very difficult or impossible to treat the infections they cause } \\
\hline True & $18(33.33 \%)$ & $23(67.65 \%)$ & $19(55.88 \%)$ & $20(71.43 \%)$ & $80(53.33 \%)$ \\
\hline False & $36(66.67 \%)$ & $11(32.35 \%)$ & $15(44.12 \%)$ & $8(28.57 \%)$ & $70(46.67 \%)$ \\
\hline Total & 54 & 34 & 34 & 28 & 150 \\
\hline \multicolumn{6}{|c|}{ Antibiotic resistance is an issue that could affect me and my family } \\
\hline Yes & $32(59.26 \%)$ & $18(52.94 \%)$ & $19(55.88 \%)$ & $16(57.14 \%)$ & $85(56.67 \%)$ \\
\hline No & $22(40.74 \%)$ & $16(47.06 \%)$ & $15(44.12 \%)$ & $12(42.86 \%)$ & $65(43.53 \%)$ \\
\hline Total & 54 & 34 & 34 & 28 & 150 \\
\hline \multicolumn{6}{|c|}{ Antibiotic resistance is an issue in other country but not here } \\
\hline False & $20(37.04 \%)$ & $8(23.53 \%)$ & $11(32.35 \%)$ & $18(64.29 \%)$ & $57(38 \%)$ \\
\hline True & $34(62.96 \%)$ & $26(76.47 \%)$ & $23(67.65 \%)$ & $10(35.71 \%)$ & $93(62 \%)$ \\
\hline Total & 54 & 34 & 34 & 28 & 150 \\
\hline \multicolumn{6}{|c|}{ Antibiotics resistance is only a problem for people who take antibiotics regularly } \\
\hline True & $20(37.04 \%)$ & $7(20.59 \%)$ & $8(23.04 \%)$ & $18(64.29 \%)$ & $53(35.33 \%)$ \\
\hline False & $34(62.96 \%)$ & $27(79.41 \%)$ & $26(76.47 \%)$ & $10(35.71 \%)$ & $97(64.67 \%)$ \\
\hline Total & 54 & 34 & 34 & 28 & 150 \\
\hline \multicolumn{6}{|c|}{ Bacteria which are resistance to antibiotics can be spread from person to person } \\
\hline True & $18(33.33 \%)$ & $12(35.29 \%)$ & $10(29.41 \%)$ & $22(78.57 \%)$ & $62(41.33 \%)$ \\
\hline
\end{tabular}




$\begin{array}{llllll}\text { False } & 36(66.67 \%) & 22(64.71 \%) & 24(70.59 \%) & 6(21.43 \%) & 88(58.67 \%) \\ \text { Total } & 54 & 34 & 34 & 28 & 150\end{array}$

Antibiotic resistance infection could make medical procedures like surgery, organ transplant, and cancer treatment much more dangerous

$\begin{array}{llllll}\text { True } & 20(37.04 \%) & 6(17.65 \%) & 5(14.71 \%) & 20(71.43 \%) & 51(34 \%) \\ \text { False } & 34(62.96 \%) & 28(82.35 \%) & 29(85.29 \%) & 8(28.57 \%) & 99(66 \%) \\ \text { Total } & 54 & 34 & 34 & 28 & 150\end{array}$

Antibiotic resistance in human can occur from indiscriminate use of antibiotics in animal

$\begin{array}{llllll}\text { TRUE } & 23(42.59 \%) & 13(38.24 \%) & 15(44.12 \%) & 19(67.86 \%) & 70(46.67 \%) \\ \text { False } & 31(57.41 \%) & 21(61.76 \%) & 19(55.88 \%) & 9(32.14 \%) & 80(53.33 \%) \\ \text { Total } & 54 & 34 & 34 & 28 & 150\end{array}$

Sub optimal dosing of antibiotics in animal can lead to antibiotic resistance in animal

\begin{tabular}{llllll} 
True & $25(46.30 \%)$ & $16(47.06 \%)$ & $6(17.65 \%)$ & $20(71.43 \%)$ & $67(44.67 \%)$ \\
False & $29(53.70 \%)$ & $18(52.94 \%)$ & $28(82.35 \%)$ & $8(28.57 \%)$ & $83(55.33 \%)$ \\
Total & 54 & 34 & 34 & 28 & 150 \\
\hline
\end{tabular}

Table 6. Common antibiotics use and active ingredients

\begin{tabular}{|c|c|c|c|c|c|c|}
\hline Active ingredient & Antibiotic & Poultry & Fishery & Cattle & $\begin{array}{l}\text { Vet shop } \\
\text { operators }\end{array}$ & Overall \\
\hline Tetracycline & Oxytetracycline & $42[77.78 \%]$ & $25[73.53 \%]$ & $16[47.06 \%]$ & $25[89.29 \%]$ & $72 \%$ \\
\hline Tetracycline & Doxycycline & $2[3.70 \%]$ & $1[2.94 \%]$ & $0[0 \%]$ & $23[82.14 \%]$ & $17.33 \%$ \\
\hline Aminoglycoside & Neomycin & $14[25.93 \%]$ & $1[2.94 \%]$ & $0[0 \%]$ & $13[46.43 \%]$ & $18.67 \%$ \\
\hline Aminoglycoside & Streptomycin & $37[68.52 \%]$ & $15[44.12 \%]$ & $12[35.29 \%]$ & $20[71.43 \%]$ & $56 \%$ \\
\hline Aminoglycoside & Gentamicin & $7[12.96 \%]$ & $0[0 \%]$ & $4[11.76 \%]$ & $1[39.29 \%]$ & $8 \%$ \\
\hline Penicillin & Benzypenicillin & $6[11.11 \%]$ & $4[11.76 \%]$ & $2[5.88 \%]$ & $5[17.86 \%]$ & $11.33 \%$ \\
\hline Penicillin & Procaine penicillin & $4[7.41 \%]$ & $0[0 \%]$ & $0[0 \%]$ & $13[46.43 \%]$ & $11.33 \%$ \\
\hline Fluoroquinolones & Norfloxacin & $5[9.26 \%]$ & $1[2.94 \%]$ & $1[2.94 \%]$ & $15[53.57 \%]$ & $14.67 \%$ \\
\hline Fluoroquinolones & Enrofloxacin & $4[7.41 \%]$ & $1[2.94 \%]$ & $1[2.94 \%]$ & $11[39.29 \%]$ & $11.33 \%$ \\
\hline Fluoroquinolones & Tyrosine & $6[11.11 \%]$ & $3[8.82 \%]$ & $4[11.76 \%]$ & $18[64.29 \%]$ & $20.67 \%$ \\
\hline Macrolide & Erythromycin & $1[1.85 \%]$ & $0[0 \%]$ & $1[2.94 \%]$ & $3[10.71 \%]$ & $3.33 \%$ \\
\hline
\end{tabular}


Table 7. Purpose of Antimicrobial Use in Selected Farms

\begin{tabular}{llll}
\hline Diseases & $\begin{array}{l}\text { Poultry } \\
\mathrm{n}(54)\end{array}$ & $\begin{array}{l}\text { Fishery } \\
\mathrm{n}(34)\end{array}$ & $\begin{array}{l}\text { Cattle } \\
\mathrm{n}(34)\end{array}$ \\
\hline Gomboro & $27(50 \%)$ & $0(\%)$ & $0(0 \%)$ \\
Newcastle & $25(46.30 \%)$ & $0(0 \%)$ & $0(0 \%)$ \\
CRD & $50(92.59 \%)$ & $0(0 \%)$ & $0(0 \%)$ \\
Coryza & $23(42.59 \%)$ & $0(0 \%)$ & $0(0 \%)$ \\
Coccidiosis & $37(68.52 \%)$ & $(0 \%)$ & $0(0 \%)$ \\
Worms & $31(57.41 \%)$ & $30(88.24 \%)$ & $19(55.88 \%)$ \\
Prophylaxis & $43(79.63 \%)$ & $29(85.29 \%)$ & $15(44.12 \%)$ \\
Others & $17(31.48 \%)$ & $20(58.82 \%)$ & $8(23.53 \%)$ \\
\end{tabular}

Table 8. Knowledge about Antibiotics

\begin{tabular}{|c|c|c|c|c|c|c|}
\hline & & $\begin{array}{l}\text { Poultry } \\
\mathrm{n}(54)\end{array}$ & $\begin{array}{l}\text { Fishery } \\
\mathrm{n}(34)\end{array}$ & $\begin{array}{l}\text { Cattle } \\
\mathrm{n}(34)\end{array}$ & Vet shop operators $\mathrm{n}(28)$ & Overall \\
\hline \multirow[t]{2}{*}{ Super bugs } & Yes & $28(51.85 \%)$ & $6(17.65 \%)$ & $14(41.18 \%)$ & $16(57.14 \%)$ & $64(42.67 \%)$ \\
\hline & No & $26(48.15 \%)$ & $2882.35 \%)$ & $20(58.82 \%)$ & $12(42.86 \% 0$ & $86(57.33 \%)$ \\
\hline \multirow[t]{2}{*}{ Antibiotics resistance bacteria } & Yes & $31(57.41 \%)$ & $14(41.18 \%)$ & $9(26.47 \%)$ & $19(67.86 \%)$ & $72(48.67 \%)$ \\
\hline & No & $23(42.59 \%)$ & $20(58.82 \%)$ & $25(73.53 \%)$ & $9(32.14 \%)$ & $77(51.33 \%)$ \\
\hline \multirow[t]{6}{*}{ Where did you hear about it? } & 1. Doctor & $12(22.22 \%)$ & $5(14.71 \%)$ & $0(0 \%)$ & $1(3.57 \%)$ & $18(12 \%)$ \\
\hline & 2. Pharmacist & $10(18.51 \%)$ & $5(14.71 \%)$ & $1(2.94 \%)$ & $7(25 \%)$ & $23(15.33 \%)$ \\
\hline & 3. Family member & $15(27.78 \%)$ & $5(14.71 \%)$ & $3(8.82 \%)$ & $0(0 \%)$ & $23(15.33 \%)$ \\
\hline & 4. Media & $12(22.22 \%)$ & $10(29.41 \%)$ & $1(2.94 \%)$ & $4(14.29 \%)$ & $27(18 \%)$ \\
\hline & 5. Specific campaign & $5(9.26 \%)$ & $1(2.94 \%)$ & $0(0 \%)$ & $11(39.29 \%)$ & $17(11.33 \%)$ \\
\hline & Others & $0(0 \%)$ & & $0(0 \%)$ & $5(17.86 \%)$ & $6(4 \%)$ \\
\hline
\end{tabular}




\section{DISCUSSION}

The present study was undertaken to investigate antibiotics usage by livestock farmers in Oyo town, Oyo State Nigeria. The massive use of antimicrobial agents in agriculture has supported the intensification of modern food-animal production since the early 1960s by facilitating early weaning, higher animal stocking densities, and the use of cheaper feed sources, among others, and has most likely contributed to increased outputs and lower prices of meat (Wegener, 2012). The findings in the present survey revealed that the majority of the respondents were males constituting $72 \%$ of the farmers. This finding concurs with a recent study conducted on commercial poultry layer farmers in southwest Nigeria by Adebowale et al., (2016) in which they reported $71.8 \%$ of respondents as men and $14.6 \%$ as women. The present study also reports that higher percentage $(36 \%)$ of respondents were between 41 to 50 years of age (adults) as at the time of data collection and were the major livestock farmers observed during the course of the study. This might suggest that age is significant in livestock management. Similar finding was observed in a recent study (Adebowale et al., 2016) where $83.5 \%$ of the respondents were reported to have attended tertiary education. One must be an adult to acquire this level of education. However, age is insignificant in livestock management when experience is the point of consideration. .

Antibiotics used in veterinary practice are in the form of therapeutic, prophylactic and growth promoters and can be used rationally or irrationally (Beyene and Tesega, 2014; Gilbert, 2012). The findings in this study indicated that farmers administered antibiotics on their animals when the animals were sick (for treatment), to prevent secondary bacterial infection after a viral infection and on healthy animals (for prophylaxis). Similar observations were reported recently in poultry production systems in Nigeria (Adebowale et al., 2016; Oluwasile et al.,2014; Geidam et al., 2012), Cameroon (Kamini et al., 2016), Ghana (Boamah et al., 2016)and Brazil (Medeiros et al., 2011) in which antibiotics were administered for treatment and prophylaxis, and as growth promoters. This routine practice of administering antibiotic agents to domestic livestock for treatment, prophylaxis as well as, for growth promotion, is mostly found to influence the emergence of antibioticresistant bacteria that are subsequently transferred to humans through the food chain (Guetiya et al., 2016; Carlet et al., 2012;Byarugaba et al., 2011; Silveira et al., 2009;). Although, antibiotics use as growth promoter or feed supplements have been found to improve feed conversion efficiency and increase weight gain in livestock animals (Graham et al., 2007), irrational use of antibiotics on animals has caused treatment failures in many conditions and consequent drug residual effecting edible livestock products (meat, milk and egg) upon consumption by humans of insufficiently cooked products (Lawal et al., 2015; Vitomir et al., 2011) due to overuse of antibiotics in food animals. Fish farmers use antibiotics and other antimicrobial agents mostly for the prevention and treatment of diseases in fish (Bager, 1997). Though some farms do not use antibiotics directly, fish farming practices such as the use of animal manure, waste water, human excreta in fish farms and disposal of untreated effluents from fish farms may contribute to antibiotic resistance in fish farms and adjoining water bodies (Cox and Snell, 1989; Coyne et al., 1994).

In this study oxytetracycline was observed as the most common and frequently selected antibiotic by farmers, followed by tetracycline and collotin 
antibiotics. Tetracyclines and aminoglycosides were reported as the most frequently used antibiotics in chickens in Maiduguri (Akidarju et al., 2010) in agreement with the finding in this study. Also supporting the findings in this study were studies in poultry production in Ogun, Southwest Nigeria where Awosile et al. (2014) reported that antibiotics were commonly administered either for therapy $(36.2 \%)$, prophylaxis $(29.3 \%)$, or both $(32.8 \%)$ and to lesser extent for growth promotion $(6.9 \%)$. While Neoceryl ${ }^{\mathrm{R}}$ (a commercially prepared broad spectrum antibiotics consisting of neomycin, erythromycin, oxytetracycline, streptomycin and colistin), Enrofloxacin and Furazolidone were the commonest antibiotics used. Similarly, in South Africa, Horton et al., (2011) reported tyrosine, followed by tetracyclines, oxytetracycline and penicillins as the most frequently used antibiotics in poultry. Farmers have easy access to antibiotics without a doctor's reference this could lead to abuse of antibiotics. Unfortunately, drug residues induces resistance and ineffectiveness of the drug (Donkor et al., 2011). WHO (2011) referred to this development as one of the most serious risks to human health at the global level. Farmers are important actors in modulating their on-farm antimicrobial use (Kramer et al., 2017). In this study, the knowledge of antibiotic resistance, superbug and antibiotic resistance bacteria was low among the farmers and this is seen as an impediment to controlling antibiotic resistance in both animal and humans. A high percentage of the farmers interviewed did not believe that antibiotic resistance can be transmitted from person to person and from animals to humans. These responses by farmers were found to be false because according to Canada et al (2017) the accumulated scientific evidence that some uses of antibiotics in food-producing animals can lead to antibiotic resistance in intestinal bacteria, and this resistance can then be transmitted to the general population, causing treatment-resistant illness. The use of antibiotics in food-producing animals can also create antibiotic resistance in nonpathogenic bacteria, the resistance genes can then be transferred to disease-causing bacteria, resulting in antibiotic-resistant infections for humans. It has also been confirmed that livestock manure disposal is one of the biggest ways antibiotic residues and resistant bacteria enter the environment.

The most popular route of communication through which farmers got their information about drug and drugrelated issues was the media. Abubakar et al.,(2009) in their study shows that access to mass media on agricultural information of farmers in Kebbi state is through radio and television, and most of them indicated that the media sources are conventional, accessible and preferred to listen to the agricultural programmes in the night time (8pm -11.59pm). Scanfeld et al. (2010) in his research on the dissemination of health information through social networks like Twitter concluded that social media sites offer a means of sharing health information. Hence the media, both conventional and social was found to be efficient means of dissemination of information about use of antibiotics and potentials for antibiotic resistance in animals which can be transferred to humans. Generally speaking, mass media help extension agents to reach large numbers of farmers simultaneously. However, there is little opportunity for these farmers to interact among themselves or to provide feedback to the extension agents (van der Mheen-Sluijer, 1995).

Infections with antibiotic-resistant bacteria result in increased mortality, morbidity, and social and economic costs (de Kraker et al. 2011; Cosgrove and Carmeli, 2003; Cosgrove, 2006). By 2050, an estimated 10 million deaths per year 
globally will be attributable to antimicrobial resistance, with a cumulative economic cost of US $\$ 100$ trillion.

WHO has created a set of strategies to combat rising antibiotic resistance, which include improving sanitation and hygiene to reduce overall infection rates, and optimising the use (and preventing the overuse) of antibiotics in both humans and animals (WHO, 2015). In the battle against antibiotic resistance, greater emphasis should be placed on disease prevention, which includes strengthening hygiene and control practices and improving sanitation. Nigeria can learn from Australia which has extensive livestock production systems with comparably low use of antimicrobials due to strict biosecurity measures and regulatory control of veterinary chemicals which have contributed to a low antimicrobial risk status in food-producing animals (DPIRD, 2018). Organic farming is another way of reducing antimicrobial resistance, according to Misiewicz and Shade (2016) that organic livestock production, which prohibits the use of antibiotics for growth promotion or prophylactic purposes, provides a compelling example of successful, profitable operations and demonstrates the ability of livestock farms to operate without substantial antibiotic use.

\section{CONCLUSION}

There is need for public awareness through media programmes to educate the populace of the risk of consuming livestock products with illegal levels of antibiotic residues. The Federal and State Government authorities of Nigeria should mandate a legislation regarding drug use and veterinary drug residue control. They should also provide some basic facilities for nationwide specific residue monitoring programme and periodic surveillance of antibioticresidues in edible tissues at the level of abattoir, farms, market etc.

\section{REFERENCES}

Adebowale, O.O., Adeyemo, O. K., Awoyomi, O., Dada, R. and Adebowale, O. 2016. Antibiotic use and practices in commercial poultry laying hens in Ogun state, Nigeria. Revue d'ElevageMédecineVétérinaire des Pays Tropicaux 69(1): 41 - 45.

Abubakar, B.K.,Ango, A.K., andBuhar, U.2009. The Roles of Mass Media in Disseminating Agricultural Information to Farmers in Birnin Kebbi Local Government Area of KebbiState: A Case Study of State Fadama II Development Project. Journal of Agricultural Extension. 13(2): 42-54.

Awosile, B. B., Agbaje, M.,Ojo, E.O., Dipeolu, M. 2014. Antibiotic usage pattern in selected poultry farms in Ogun state. Sokoto Journal of Veterinary Sciences 12;45-50.

Akidarju, M.S., Onyemaechi, E.G. and Dauda, M.G. 2010. An assessment of some poultry management practices and disease recognition by poultry farmers in Maiduguri Arid zone, Nigeria. World's Poultry ScienceJournal, 66: 285 - 298.

Bager, F., M. Madsen, J. Christensen, and F. M. Aarestrup (1997). Avoparcin used as a growth promoter is associated with the occurrence of vancomycin-resistant Enterococcus faecium in Danish poultry and pig farms. Preventive Veterinary Medicine, 31:95-112.

Beyene, T. and Tesega, B. 2014. Rational veterinary drug use: Its significance in public health. Journal of Veterinary Medicine and Animal Health, 6(12): 302 $-308$.

Binh, C.T.T., Heuer, H., Kaupenjohann, M.and Smalla, K. 2008. Piggery manure used for soil fertilization is a reservoir for transferable antibiotic resistance plasmids. FEMS Microbiology Ecology, 66(1): $25-37$.

Boamah, VE., Agyare, C., Odoi, H. and Dalsgaard, A. 2016. Practices and factors influencing the use of antibiotics in 
selected poultry farms in Ghana. Journal of Antimicrobial Agents, 2:120. Doi: 10.4172/2472-1212.1000120.

Bondt, N, Jensen, V.F., Puister-Jansen, L.F., and van Geijswijk, I.M. 2013. Comparing antimicrobial exposure based on sales data. Preventive Veterinary Medicine, 108: 10 - 20.

Byarugaba, D.K., Kisame, R. and Olet, S. 2011. Multidrug resistance in commensal bacteria of food of animal origin in Uganda. African Journal of Microbiology Research, 5(12): 1539 1548.

Callens, B., Persoons, D.,Maes, D.,Laanen, M., Postma, M., Boyen, F.,Haesebrouck, F.,Butaye, P.,Catry, B. and Dewulf, J. 2012. Prophylactic and metaphylactic antimicrobial use in Belgian fattening pig herds. PreventiveVeterinary Medicine Elsevier, 106: 53 - 62.

Cañada, F.C., Muñoz de la Peña, A. andEspinosa-Mansilla, A. 2009. Analysis of antibiotics in fish samples. from:

https://www.researchgate.net/publicati on/26298266_Analysis_of_antibiotics_i n_fish_samples[accessed Jan 20 2019].

Carlet, J., Jarlier, V.,Harbath, S., Voss, A., Goossens, H. and Pittet, D. 2012. The participants of the 3rd World Healthcare-Associated Infections Forum. Ready for a world without antibiotics? The Pensiéres Antibiotic Resistance Call to Action. Antimicrobial Resistance and Infection Control, 1: 11. Doi: 10.1186/2047-2994-1-11.

Chantziaras, I.,Boyen, f., Callens, B. and Dewulf, J. 2014. Correlation between veterinary antimicrobial use and antimicrobial resistance in foodproducing animals: a report on seven countries. Journal of AntimicrobialChemotherapy, 69: 827 834.

Cogliani, C., Goossens, H. and Greko, C. 2011. Restricting antimicrobial use in food animals: A lesson from Europe. Microbe, 6: $274-279$.

Cosgrove, S.E.(2006) The relationship between antimicrobial resistance and patient outcomes: mortality, length of hospital stay, and health care costs. Clinical Infectious Diseases 42: S82-S89

Cosgrove, S.E. and Carmeli, Y. (2003). The impact of antimicrobial resistance on health and economic outcomes. Clinical Infectious Diseases 36: 1433-1437

Cox, D. R. and Snell, E. J. (1989). The analysis of binary data. Chapman \& Hall, London, United Kingdom.

Coyne, R., M. Hiney, B. O'Connor, J. Kerry, D. Cazabon, and P. Smith (1994). Concentration and persistence of oxytetracycline in sediments under a marine salmon farm. Aquaculture 123:31-42.

de Kraker, M.E., Davey, P.G. and Grundmann, H. (2011)Mortality and hospital stay associated with resistant Staphylococcus aureus and Escherichia coli bacteremia: estimating the burden of antibiotic resistance in Europe. PLoS Medicine, 8: e1001104

Department of Primary Industries and Regional Development (DPIRD) (2018) Preventing. antimicrobial resistance.https://www.agric.wa.gov.au/ livestock-biosecurity/preventingantimicrobial-resistance . Accessed on 23rd April, 2019.

Dipeolu, M.A. and Alonge, D.O. 2002. Residue of Streptomycin in meat sold for human consumption in some states of SW Nigeria. Archivos de Zootecnia., 51:447-480.

Dipeolu, M.A. 2004. Problems and prospects of antibiotics residues in meat products in Nigeria Vom. Journal of Veterinary Sciences, 1(1): 63-67.

Donkor, E.S., Newman, M.J. and YeboahManu, D. 2012. Epidemiological aspects of non-human antibiotic usage and resistance: implications for the control of antibiotic resistance in Ghana. 
Tropical Medicine andInternal Heat, 17: 462 - 468.

Donoghue, D.J. 1998. Investigating drugs transfer into eggs. U.S. Food and Drug Administration Vet. Newsletter, XIII(1).

Donoghue, D.J. 2001. Mechanism regulating drug and pesticide residue uptake by egg yolks: Development of predictive models. World's Poultry Science Journal, 57: 275-380.

Donoghue, D.J. 2003. Antibiotic residues in poultry tissues and eggs: Human health concerns? Poultry Science, 82: 618-621.

Doyle, M.E. 2006. Veterinary drug residues in processed meats potential health risk: A review of the scientific literature. Food Research Institute, University of Wisconsin,

Madison,https:// fri.wisc.edu/files/Brief s_File/FRIBrief_VetDrgRes.pdf:1-11.

Accessed on 21/1/2019.

Eltayb, A., Barakat, S.,Marrone, G.,Shaddad, S. and Lundborg, C. S. 2012. Antibiotic use and resistance in animal farming: A quantitative and qualitative study on knowledge and practices among farmers in Khartoum, Sudan. Zoonoses and Public Health, 59: $330-338$.

Garfoth, C. 2015. Livestock keepers' reasons for doing and not doing things which governments, vets and scientists would like to do. Zoonosis and Public Health, 62: $29-38$.

Geidam, Y.A., Ibrahim, U.I.,Grema, H.A.,Sanda, K.A., Suleiman, A. and Mohzo, D.L. 2012. Patterns of antibiotics sales by drug stores and usage in poultry farms: A questionnaire -based survey in Maiduguri, Northeastern Nigeria. Journal of Animal and Veterinary Advances, 11(16): 2852 1855.

Geidam, Y.A., Usman, H., Musa, H.I., Anosike, F. and Adeyemi, Y. 2009. Ox tetracycline and Procain. Penicillin residues in tissues of slaughtered cattle
inMaiduguri, Bornostate, Nigeria. Terrestrial and Aquatic Environmental Toxicology, 3(2): 68-70.

Gilbert, N. 2012. Rules tighten on use of antibiotics on farms. Nature, 481: 125.

Gilchrist, M.J., Greko, C., Wallinga, D.B.,Beran, G.W., Riley, D. G. and Thorne, P.S.(2007). The potential role of concentrated animal feeding operations in infectious disease epidemics and antibiotic resistance. EnvironmentalHealth Perspectives, 115(2): 313 - 316.

Graham, R., Graham, C. and McMullam, G. 2007. Microbial proteomics: a mass spectrometry primer for biologists. Microbial Cell Factories, 6:26.

Grave, K., Torren-Edo, J. and Mackay, D. 2010. Comparison of sales of veterinary antibacterial agents between 10 European countries. Journal of Antimicrobial Chemotherapy, 65(9): 2037 - 2040.

Green, A.L., Carpenter, L.R.,Edmisson, D.E., Lane, C.D., Welborn, M.G., Hopkins, F.M.,Bemis, D.A. and Dunn, J.R. 2010. Producer attitudes and practices related to antimicrobial use in beef cattle in Tennessee. Journal of theAmerican Veterinary Medical Association, 237(11): 1292 - 1298.

Guetiya, W.R.E., Zambou, N.F.,Anyangwe, F.F.,Njimou, J.R., Coman, M.M.,Verdenelli, M.C., Cecchini, C.,Silvi, S., Orpianesi, C., Cresci, A. and Colizzi, V. 2016. Abusive use of antibiotics in poultry farming in Cameroon and the public health implications. British Poultry Science, 57(4):483-493

Hirsh, D.C., and Zee, Y.C. 1999. Veterinary Microbiology, 1st edn. Blackwell Publishing Company, California, pp 48 - 57.

Horton, R.A., Randall, L.P., Snary, E.L., Cockrem, H., Lotz, S., Wearing, H., Duncan, D., Rabie, A., McLaren, I., Watson, E., La Ragione, R.M. and 
Coldham, N.G.2011. Fecal carriage and shedding density of CTX-M extendedspectrum -lactamase-producing Escherichia coli in cattle, chickens, and pigs: implications for environmental contamination and food production. Applied and Environmental Microbiology, 77:3715-3719.

Javadi, A. 2011. Effect of roasting, boiling and microwave cooking methods on doxycycline residues in edible tissues of poultry by microbial method. African Journal of Pharmacy and Pharmacology, 5(8): $1034-1037$.

Kamini, M.G., Keutchatang, F.T., Mafo, H.Y.,Kansci, G. and Nama, G.M. 2016. Antimicrobial usage in the chicken farming in Yaoundé, Cameroon: a crosssectional study. International Journal of Food Contamination,3:10.

Kramer, T., Jansen, L.E., Lipman , L. J.A., Smit , L.A.M., Heederik, D. J.J., Dorado-García,A. 2017. Farmers' knowledge and expectations of antimicrobial use and resistance are strongly related to usage in Dutch livestock sectors. Preventive Veterinary Medicine,147: 142-148 (Available from: https://www.researchgate.net/publicati on/319574517_Farmers\%27_knowledge _and_expectations_of_antimicrobial_us e_and_resistance_are_strongly_related_t o_usage_in_Dutch_livestock_sectors [accessed Jan 20 2019].

Lawal, J.R., Saleh, M.J.,Yaqub, A.G., Amina, M.B.,Yakaka, W. and Muhammad, M. 2015. Antibiotic residues in edible poultry tissues and products in Nigeria: A potential public health hazard. International Journal of Animaland Veterinary Advances, 7(3): $55-61$.

Medeiros MAN., DCN Oliveira, DP Rodrigues, and DRC Freitas (2011). Prevalence and antimicrobial resistance of salmonella in chicken carcasses at the retail in 15 Brazilian cities.
RevistaPanamericana de SaludPública, 30(6): $555-560$.

Moyane JN., AIO Jideani, and OA Aiyegoro (2013). Antibiotics usage in food-producing animals in South Africa and impact on human: antibiotic resistance. African Journal of Microbiology Research, 7(24): 2990 2997.

Misiewicz, T. and Shade, J. (2016). Organic Food and Farming as a Tool to Combat Antibiotic Resistance and Protect Public Health. https://www.organiccenter.org/wpcontent/uploads/2016/07/TOC_Repor t_AntibioticResistance_FINAL.pdf

Olatoye, I.O. and Ehinwomo, A.A. 2009. Oxytetracycline Residues in Edible tissues of cattle slaughtered in Akure, Nigeria. Internet J. Food Safety, 11: 6266.

Oluwasile, B.B., Agbaje, M., Ojo, O.E and Dipeolu, M.A.2014. Antibiotic usage pattern in selected poultry farms in Ogun state. Sokoto Journal of Veterinary Science, 12(1): $45-50$.

Phillips, I., Casewell, M., Cox, T., De Groot, B., Friis, C., Jones, R., Nightingale, C., Preston, R. and Waddell, J. 2004. Does the use of antibiotics in food animals pose a risk to human health?. A critical review of published data. Journal of Antimicrobial Chemotherapy, 53: $28-52$.

Sasanya, J.J., OgwalOkenga, J. W., Etobi, F. and Muganwa, M. 2005. Use of Sulfonamides in layers in Kampala district, Uganda and sulfonamide residues in commercial eggs. African Health Science, 5(1):33-39.

Sawant, A.A., Sordillo, L.M. and JayaraoB. M. 2005. A survey on antibiotic usage in dairy herds in Pennsylvania. Journal of Dairy Science, 88: 2991 - 2999

Scanfeld, D., Scanfeld, V. and Larson E. L. 2010. Amerika (US). American Journal of Infection Control, 38(3):182-188. 
Shareef, A.M., Jamel, Z.T. and Yonis, K.M. 2009. Detection of antibiotic residues in stored poultry products. Iraq Journal of. Veterinary Science, 23(1): 4548.

Silley, P., Simjee, S., and Schwarz, S. 2012. Surveillance and monitoring of antimicrobial resistance and antibiotic consumption in humans and animals. Review in Science and Technology Office InternationalEpizootics, 31(1): $105-120$.

Silveira, M.E., Freitas, A.R.,Peixe, L. and Novais, C. 2009. Environmental spread of antibiotic molecules, antibiotic resistant bacteria and genes: jigsaw pieces of a public health problem. Revista da Faculdade deClénclas da Saúde.

Porto:

EdicóesUniversidadeFernando

Pessoa,6:244 - 253.

Simon, A.H. and Baxter, G.A. 2006. Biosensor screening for veterinary drug residues in food stuffs. Journal of AOAC International, 89(3): 862-867.

Van Boeckel, T.P., Brower, C., Gilbert, M., Grenfell, B.T., Levin, S.A., Robinson, T. P.,Teillant, A. and Laxminarayan, R. 2015. Global trends in antimicrobial use in food animals. Proceeding of the National Academy of Science, 112(18): 5649 - 5654. Available at www.pnas.org/cgi/doi/10.1073/pnas.15 03141112.

van der Mheen-Sluijer, J. (2016). Aquaculture extension guidelines for small scale farmers: Based on experiences from a pilot project in Eastern Province, Zambia. Aquaculture for Local Community Development Programme GCP/RAF/277/BEL ALCOM Report No. 16 http://www.fao.org/3/ad785e/AD785 E00.htm\#TOC

Vitomir C., Silva, D., Biljana, A. and Sanja, C. 2011. The significance of rational use of drugs in veterinary medicine for food safety. Technological Mesa, 52(1): 74 79.

Wegener, C.H. (2012). Antibiotic resistance-Linking human and animal health in Improving Food Safety Through a One Health Approach: Workshop Summary. National Academies Press (US). https://www.ncbi.nlm.nih.gov/books/ NBK114485/.

WHO (2011): Action Plan Against The Rising Threats From Antimicrobial Resistance; Communication from the Commission to the European Parliament and Council 2011. https://ec.europa.eu/health/amr/sites/ amr/files/communication_amr_2011_7 48_en.pdf

WHO 2012. The evolving threat of Antimicrobial

Resistance.who.int/iris/bitstream/handl e/10665/44812/9789241503181_eng.pd f;jsessionid $=8$ FABE44E58EB8D230F19 9267109D7DF7 (Accessed 21/01/2019)

WHO (2015). Antimicrobial resistance: global antimicrobial resistance surveillance system: manual for early implementation.

http://www.who.int/antimicrobialresistance/publications/surveillancesystem-manual/en/

Zwald, AG., Ruegg, P. L., Kaneene, J. B., Warnick, L. D., Wells, S. J., Fossier, C. and Halbert, L.W. 2004. Management practices and reported antimicrobial usage on conventional and organic dairy farms. Journal of Dairy Science, 87: 191 -201 . 